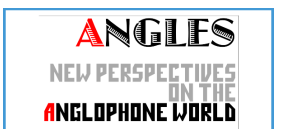

ANELOPHONE WORLD

\section{Angles}

New Perspectives on the Anglophone World

9| 2019

Reinventing the Sea

\title{
Salman Rushdie's Sea World: Haroun and the Sea of Stories
}

\section{Ludmila Volná}

\section{(2) OpenEdition \\ Journals}

\section{Electronic version}

URL: https://journals.openedition.org/angles/843

DOI: 10.4000/angles.843

ISSN: 2274-2042

\section{Publisher}

Société des Anglicistes de l'Enseignement Supérieur

\section{Electronic reference}

Ludmila Volná, "Salman Rushdie's Sea World: Haroun and the Sea of Stories", Angles [Online], 9 | 2019, Online since 01 November 2019, connection on 06 June 2022. URL: http://journals.openedition.org/ angles/843; DOI: https://doi.org/10.4000/angles.843

This text was automatically generated on 6 June 2022.

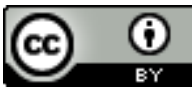

Angles est mise à disposition selon les termes de la Licence Creative Commons Attribution 4.0 International. 


\title{
Salman Rushdie's Sea World: Haroun and the Sea of Stories
}

\author{
Ludmila Volná
}

1 Salman Rushdie's style of writing is more often than not classified as magic realism, a term used since the 1920s to refer to works which combine realistic depictions with elements of fantasy, supernatural and magic. When the term was first used in 1956 in a wider post-colonial context by Jacques Stephen Alexis, it was in an attempt to

reconcile the arguments of post-war, radical intellectuals in favour of social realism as a tool for revolutionary social representation, with a recognition that in many post-colonial societies a peasant pre-industrial population had its imaginative life rooted in a living tradition of the mythic, the legendary and the magical. (Ashcroft et al. [2000] 2007: 131)

Rushdie's narrative tools are multiple and varied with regards to the elements of the imaginative life of Indian culture, and the mythic, the legendary and the magical are somehow always part and parcel of all his works. Despite previous studies on the magical elements in Haroun and the Sea of Stories (1991, hereafter referred to as H), especially those referring to fairy tale (Gonzalez, Teverson), the manner in which the mythic and the legendary are woven into the fabric of the text deserves further scrutiny. This essay argues that Rushdie creates his story world by drawing on a theoretical conceptualization of story grounded in Indian cultural perceptions and that notions of stories and storytelling point, as does the Hindu mythology dealing with water/the sea, to the psychology of the "I" as an interaction between different realities. We will see how accessing the unconscious symbolised by water and its transformative power is what makes it possible to overcome a difficult situation and to retrieve an identity that has resisted a totalitarian situation. Here, the "pursuit of folk narrative tradition" becomes related to "a dynamic part of contemporary political struggle" the function of which is "[quoting Fanon] 'to bring conflicts up to date and to modernise the kinds of struggle which the stories evoke"' (Teverson 2013: 74; Fanon 1994: 49, 47). 


\section{Stories}

3 As Rushdie wrote Haroun for his 11-year-old son Zafar Haroun, he chose the fairy tale as his narrative framework. On a superficial level, the work can be labelled simply a children's story, one told or read to children to amuse and educate them while interacting with and reinforcing their imagination. The book has significant features of a fairy tale, i.e., as Bruno Bettelheim suggests, a "mundane and simple beginning" developing into "fantastic events" and where at the end "the hero returns to reality a happy reality, but one devoid of magic" (Bettelheim 2010: 63). With this fairy tale framework in mind, Rushdie wrote to help his son and other children be "better able to meet the tasks of reality [in the same way as the hero, and to be] much better able to master life" (Bettelheim 2010: 63).

Figure 1. Illustration by Angie Brown on Haroun and the Sea of Stories by Salman Rushdie

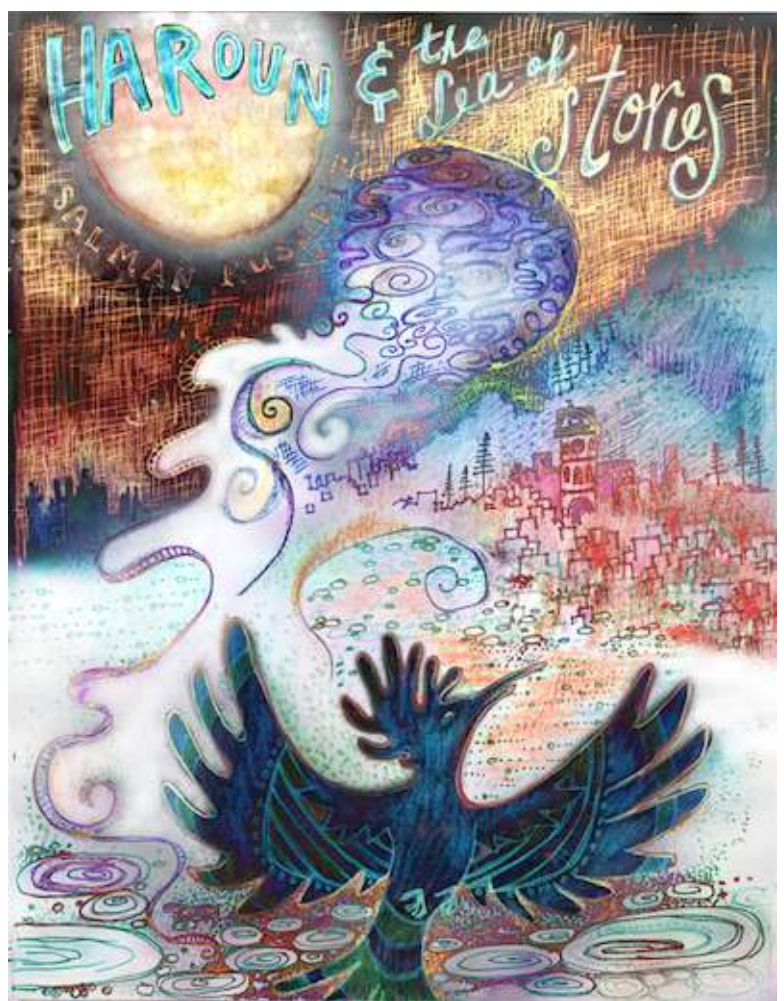

Source: https://galacticbloom.wordpress.com/2016/03/28/book-haroun-the-sea-of-stories

In order to reinforce the children's imagination, Haroun and the Sea of Stories, as well as Luka and the Fire of Life (hereafter referred to as L), which Rushdie wrote for his son Milan in 2010, the author uses language that ingeniously imitates children's parlance or thinking, with examples such as "Process Too Complicated To Explain," or "Grand Comptroller" (H 57), "Rathouse," "Bear the dog and Dog the bear," or "Level One to Level Nine" (L 34, 72, 180). The in-betweenness of languages, registers of language and the language of video games found in both works can also be understood as strategies to inscribe children's lightness of being in the reality of an adult world. The latter seems more likely when one remembers Arundhati Roy's The God of Small Things which offers examples such as "Locusts Stand I", "Prer NUN sea ayshun," etc. (Roy 1997: 36, 57) - Roy's novel, however, has nothing to do with fairy tales. 
Haroun's world is constructed around the idea of a story and Rushdie's story and storytelling device is multiple. The book is a story about story and storytelling: there is Rashid Kalifa, a storyteller and father of the protagonist, the child Haroun (Rushdie's son's namesake), both names being a clear allusion to Harun al-Rashid, the Caliph represented in One Thousand and One Nights. Rashid is also an obvious anagram of Rushdie's name (pronounced as [rashdi]), which points to Rushdie as a storyteller. The oceanic world of stories into which Haroun ventures is the moon called Kahani, meaning 'story' in Urdu/Hindi, and as applied to two locations is an evident reference to the Indian world.

6 While speaking of magic realism within the postcolonial context, Ashcroft et al. call story in the Indian cultural space a "distinctive feature of [the] local and national culture" (Ashcroft et al. [2000] 2007: 131). While resisting an "exclusive reliance on European narrative forms and European modes of perception," Andrew Teverson notices Rushdie draws on the "tradition in Indian storytelling that derives from Indic, Persian or Arabic oral and literary sources," which goes, nevertheless, far beyond what the critic classifies as a use of singular "plots and motifs" (Teverson 2001: 454-5). As Rushdie spent his formative years in India, one cannot overestimate the importance of the Indian imaginary world in his narrative. He remembers his father telling him bedtime stories that ranged from One Thousand and One Nights (generally believed to have come into existence since before the $8^{\text {th }}$ century $\mathrm{CE}$ ) to Panchatantra ( $3^{\text {rd }}$ century $\mathrm{BCE})$ and Kathasaritsagara $\left(11^{\text {th }}\right.$ century CE). The latter was translated as "Ocean of the Streams of Story," "the immense story-lake created in Kashmir where his [Joseph Anton, Rushdie's alias] ancestors had been born" (Rushdie 2013: 19). Kathasaritsagara no doubt inspired the writer in Haroun and the Sea of Stories. A significant feature of the multifaceted culture in which Rushdie grew up as a boy is the fact that myths in the form of stories are narrated to Indian children from a tender age. This practice is thus crucial to the formation of their inner world.

7 In order to understand the role and the character of the Rushdie's world of stories, it is necessary to turn to the Indian theoretical context referring to story and storytelling. Sudhir Kakar suggests that unlike in the West where history, philosophy and other human concerns were extracted from narratives and are present as refined and isolated within social sciences, "the preferred medium of instruction and transmission of psychological, metaphysical, and social thought in India continues to be the story" (Kakar 1990: 1). Stories as a way of thinking convey "what the world is like or ought to be like," and are "a perfectly adequate guide to the causal structure of reality" (2). A story in the form of myth, "in its basic sense as an explanation for natural and cultural phenomena, as an organizer of experience, is verily at the heart of the matter" (Doniger 1975: 11-2).

8 Story in Indian culture, closely related, interacting or identifying with myth, is thus both an organizing and a pedagogic tool for reality and life at an unconscious level, which is intrinsically inscribed in Haroun and the Sea of Stories. When commenting on Luka and the Fire of Life, Rushdie explained the interrelation of reality, imagination and storytelling while touching on the unconscious:

The relationship of imagination to reality is central: How does the world we make up relate to the world we live in? The imagined world impacts the real world: everything has to be imagined before it can be invented. The border between the world of fantasy, dream, imagination and the real world is fluid. This book is about 
crossing that border. The telling and receiving of stories is part of human nature.

The story instinct is hardwired in our DNA. We're storytelling animals. (Patel 2010) supply' of stories by saving their source, while he is craving for the return of his mother. In order to reach the sea world where the source is to be found, Haroun and Rashid first stop in the valley of K. which they access through the tunnel of "I." This alludes to what Madelena Gonzalez calls an "awareness of self and its shakiness," typical of Haroun's fictional world (Gonzalez 2005: 58). As the sound "I" is represented in some Central and Eastern European languages through the letter "J", the discrepancy between letters and sounds makes space for wordplay. In a letter to Georges Izambard dated 13 May 1871, French poet Arthur Rimbaud famously claimed "Je est un autre" ('I is another'). In Haroun, Rushdie plays with a foreigner's pronunciation of "Frenj"/French to indicate a different configuration of communication, or a different state of mind (H 34). In the "I", two complementary sides or aspects of one's identifying state of mind join each other: consciousness, on the one hand, and the unconscious, the dream-world of a person, on the other. The valley of $\mathrm{K}$. is thus identified as either "Kache-Mer" or "Kosh-Mar," homophones, respectively, of the French "cache-mer," "the place that hides a Sea", and "cauchemar," "a nightmare" (H 38, 40). The Dull Lake in the valley of K. where Haroun and his father embark for their trip is a clear allusion to Dal Lake in Kashmir. Contrary to its name, however, it is found to be beautiful and interesting in the same way in which the apparently 'dull' state of unconsciousness in sleep actually has an inner colourful life of its own. Rushdie's puns are textual pointers to the clash between 'the poetic reality' of the unconscious and the harsh outer reality.

\section{Myths}

11 Given the Indian cultural context, and that the sea of the Kahani moon consists of stories, one must discuss Indian imagery that deals with water and the sea. As we shall see, Hindu myths involving water emphasize the questions of reality and the unconscious. These are directly related to Haroun's adventurous trip, a voyage that will help him overcome the distressing situation of the family triggered by the departure of his mother, the book being "a novel of crisis" (Teverson 2013: 77). As myth is used "as a structural device [...] in the works of many post-colonial writers" (Innes 127), it is worthwhile to look into the theory of myths from a cultural point of view before focusing on the imagery of the relevant myths themselves. As Heinrich Zimmer explains, Indian myths "resist intellectualization" and, unlike the mythology in the West that were "re-fashioned by poetic master-minds" (e.g. Aeschylus, Sophocles, Euripides), "in the myths of India we are brought the intuitive collective wisdom of an ageless, anonymous, and many-sided civilization.[...] Details [...] strange to the Western reader must be explained" (Zimmer 1992: 41).

The retelling of myths as stories to children, a characteristic trait of Indian culture, thus doubles on the role of storytelling. As Kakar remarks, "[t]he role of myths [...] in 
defining and integrating the traditional elements and the common features of identity and society [...] cannot be over-estimated" (Kakar 1981: 5-6). The myths of a given culture, as Kakar further explains, allow an outsider to gain a psychological insight into the culture's unconscious, as they are, "in one sense [...] individual psychology projected onto the outside world; they let what is actually going on 'inside' happen 'outside" (4). Kakar refers to Robert Goldman, who suggests that "through the aesthetic power of [...] verse" myths become "more rather than less real than life" (3). In brief, myths and stories told to the young Salman Rushdie formed his unconscious in terms of culture; they were then reworked by his imagination and found expression in his work as a storyteller, emphasizing storytelling itself and its function. Rushdie's work is thus highly self-referential, especially in Haroun and the Sea of Stories. The author's inner world (rooted in the unconscious part of the mind of a child) was formed by the ways in which the Indian culture perceives and emphasizes story and storytelling, as well as by the contents of the actual stories/myths told to him as a child. The adult Rushdie became a storyteller himself and skilfully inscribes these essentials in his book.

13 The story, the unconscious, and water, and significantly water from the sea/ocean, are closely interrelated in Hindu myths. The Indian celebration of narrative owes much to the concept of higher reality (Kakar 1990:3). The Matsya Purana presents stories of a semi-divine ascetic Narada, who asked the god Vishnu to teach him the secret of Maya. In one story Vishnu lets Narada dive into a pond, and in another, to have a drink of water. In each, Narada experiences a life of a completely different being (Zimmer 1992:1). Another holy man, Markandeya, is said to be wandering inside the body of god Vishnu, perceiving and living that world's reality when he inadvertently slips out of the giant's mouth and plunges into the utterly dark and silent cosmic ocean. In despair, he ponders and asks himself whether he is dreaming, or under the spell of an illusion. The world as he had known was entirely different from this new reality, and Markandeya assumes it must have been produced by his imagination (Zimmer 1992: 38-9).

Zimmer explains the Hindu concept Maya as related to the enigma of life: "In the symbolism of the myths, to dive into water means to delve into the mystery of the Maya, to quest after the ultimate secret of life" (Zimmer 1992: 34), Maya thus encompassing "the world, the life, the ego, to which we cling" (26). Both Narada and Markandeya were, through waters, introduced to "a totally different aspect," to "the other side." Being open to various interpretations while referring to the other, these myths can be read as dealing with different realities, apparent realities and the higher reality, different worlds, and thus, with the "unconscious side of [one's] own being" (45), the parts of the self hidden in the depths of the psyche:

The imagery of the Hindu myths allows for a cautious, intuitive reading in terms of psychology - the psychology of the conscious and unconscious. Among other interpretations this approach is indeed demanded, for Maya is as much psychological as a cosmic term. (Zimmer 1992: 45)

Haroun's story warrants this approach.

On the cosmic level, a large number of Hindu myths and their variations deal both with the cycle of worlds and that of individual lives. A world, such as we know it, comes into existence at the dawn of Brahma's day. Brahma emerges from a lotus which stems out of the navel of Vishnu, and that world with all its spheres and creatures perishes at the end of Brahma's day. Here, water, in its appearance of the sea, plays a primordial role: Vishnu is represented as a giant reposing on the cosmic ocean, or in the guise of cosmic 
waters themselves. When a universe ends, it is devoured by the annihilating blaze of fire. Its debris is washed away into the cosmic ocean. Only afterwards can a new world be born out of waters again (Zimmer 1992: 35).

Figure 2. Vishnu in Anantashayan, Paata Painting on Canvas representing Vishnu, Lakshmi, Brahma and Narada

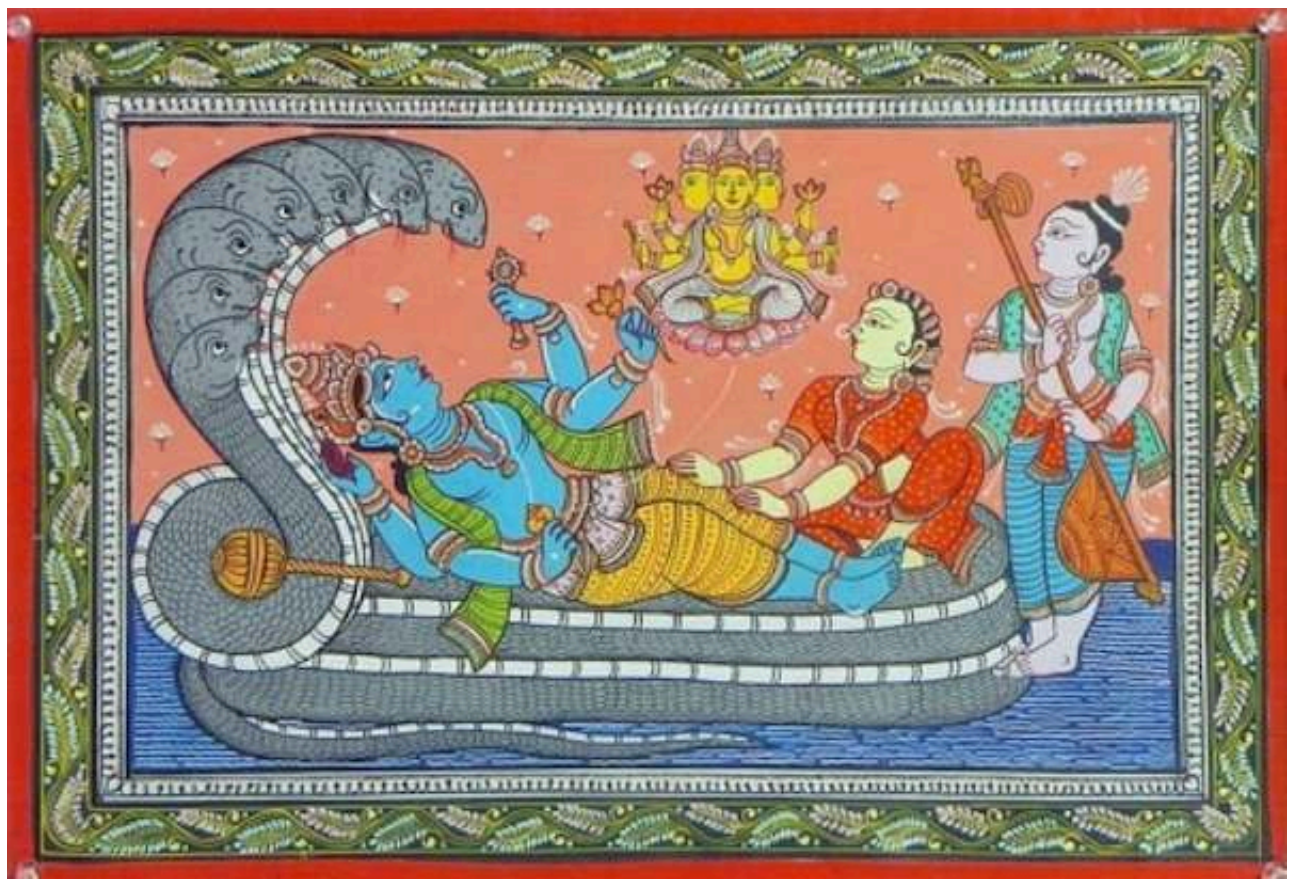

Source: Orissa State Museum, Bhubaneswar

In Haroun and the Sea of Stories, a world of the everyday (apparent) reality can first be identified. Sadness has imprisoned Haroun's city, and in its inability to identify itself, Haroun's storyteller father can no longer tell stories. The city is typically positioned in the sea and in the country of Alifbay, a name composed of the first two letters of the Arabic-based Urdu alphabet referring to a sea bay as well as to a (new) beginning. With the loss of identity and a loss of Self ("I"), a search for retrieval begins.

Rushdie takes his son "on a trip into a wondrous world" (Bettelheim 2010: 63; see also Rollason 2011) by making Rashid take Haroun on a trip to the great Story Sea, which reflects the Hindu imagery of the sea in more than one respect. Departing from the apparent reality (that corresponds to the conscious condition) through the tunnel of "I" and arriving into the oceanic world, the unconscious part of the mind (a counterpart to the conscious state) is accessed - a prerequisite to successfully cope with a tormenting situation and to retrieve a healthy identity. Haroun's experience as he lives it in Kahani's (story) sea world echoes those of Narada and Markandeya, as well as the Vishnu/Brahma myth. Haroun undertakes a voyage to "the other side" and reveals a "totally different aspect" to him and through waters an entirely new world is introduced to him. For Teverson, "[b]oth [Haroun and Luka] are fantasies that involve quests to alternative realities" (Teverson 2013: 77).

The psychological interpretation of the imagery of Maya related to water is appropriate because

Water represents the element of the deeper unconscious and contains everything tendencies, attitudes - which the conscious personality [...] has ignored and 
pushed aside. [Water] represents the indiscriminate, comprehensive potentiality of life and nature present in the individual, though split off from the perceived, realized, consciously enacted character. (Zimmer 1992:45)

Haroun's endeavour is not an easy task, however, because the two counterpart zones into which the Kahani moon is divided represent respectively a story-friendly world and one which negates the story, the Kingdom of Gup (a Hindi/Urdu word for 'gossip,' 'nonsense,' or 'fib'), a zone of eternal light, and Chup ('quiet'), immersed in perpetual darkness and ruled by the totalitarian commander Khattam-Shud, a representation of Mr Sengupta, a clerk who hates stories, with whom Haroun's mother eloped in the apparently 'real' world (the one from which Haroun originally departs). The division alludes again to storytelling, the two parts being divided by a Twilight Strip and a Chattergy Wall - Chattergy being an allusion to Bankim Chandra Chatterjee, believed to be the author of the first Indian novel. Chattergy is also a bilingual pun, playing with chatter in English and the honorific $j i$ in Hindi. Apart from story and speech as such, the realm of Gup is associated with light, brightness, colourfulness and warmth, contrary to the world of their adversaries, the Chupwallas, a world of shadow, darkness, dull discipline, silence and frost. Kahani's ocean is an Ocean of Stories consisting of warm streams of water:

He [Haroun] looked into the water and saw that it was made up of a thousand thousand thousand and one different currents, each one a different colour, weaving in and out of one another like a liquid tapestry of breathtaking complexity; and Iff [a Water Genie] explained that these were the Streams of Story, that each coloured strand represented and contained a single tale. (H 72)

Figure 3. Andy Myer. Voyage to the streams of stories

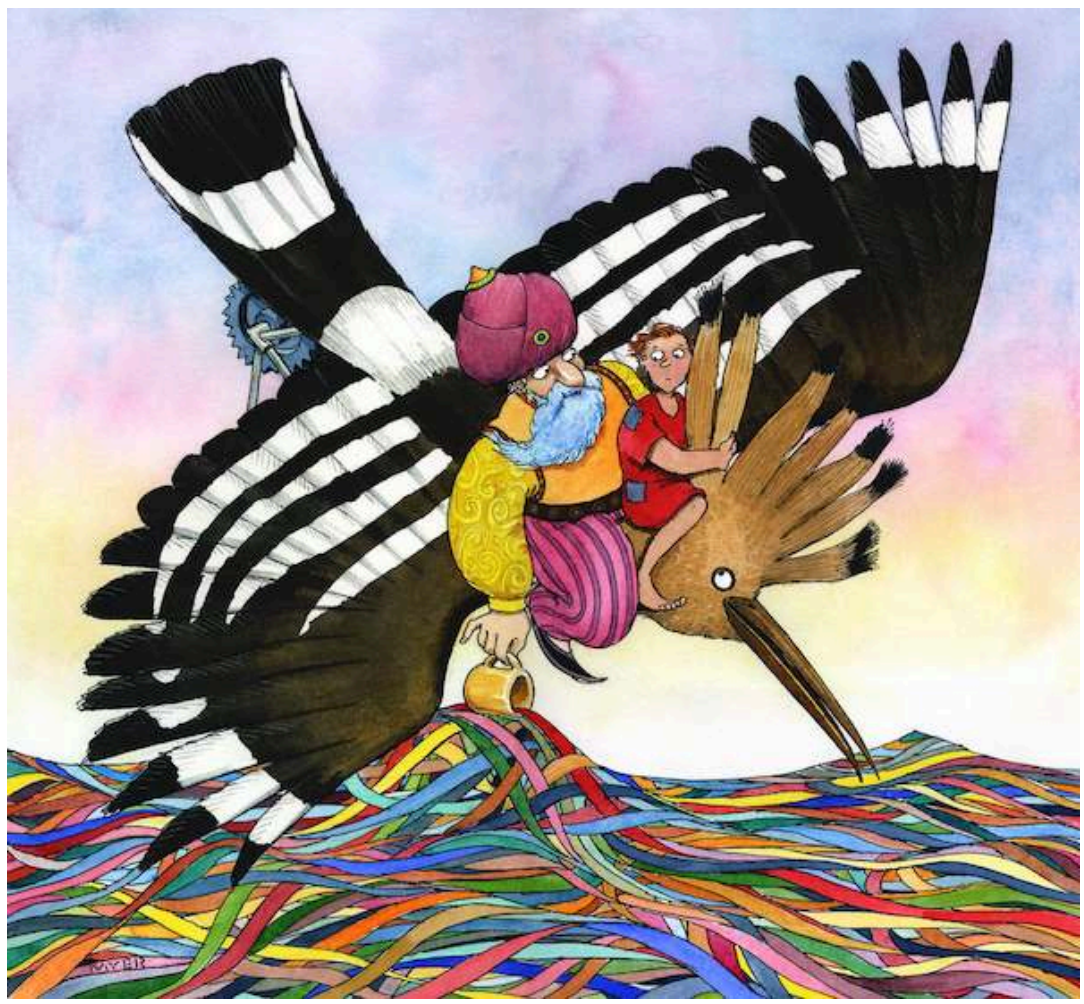

Source: http://www.andymyer.com/illustration 
The rule of Khattam-Shud, under which the Chupwallas are trying their best to poison the Ocean of Stories by fabricating anti-stories and a huge Plug to close the Source of Stories, a set of circumstances which Jean-Pierre Durix reads as "an allegory of Rushdie's personal situation," presents significant features of a totalitarian regime, in which "a writer [is] silenced by enemies of books and of the imagination" (Durix 1994: 345), by enemies of the stories. In connection with Butt the Hoopoe, a mechanical bird which carries Haroun to the Ocean of Stories, Teverson recalls the case of Farid ud-Din Attar, a poet and Sufi accused of heresy by the Persian authorities (late $12^{\text {th }}-$ early $13^{\text {th }}$ century CE), who in his Manteq at-Tair (The Conference of the Birds) introduced a hoopoe, a bird character who guides his fellow birds while telling them stories (Teverson 2001: 444-50).

\section{Totalitarianism}

The ways in which totalitarian regimes relate to stories are aptly analysed by the writer, philosopher, and theoretician of totalitarianism Václav Havel in his groundbreaking essay "Stories and Totalitarianism" (1987). Havel argues that because totalitarian ideology's grasp on the world is all-encompassing, totalitarianism denies and is directed against the mystery of life and the world and the urge to incessantly strive for disclosure and discovery. It is precisely this unending discovery that makes a story possible, a story of human life (Havel 1987).

Figure 4. Portrait of Václav Havel

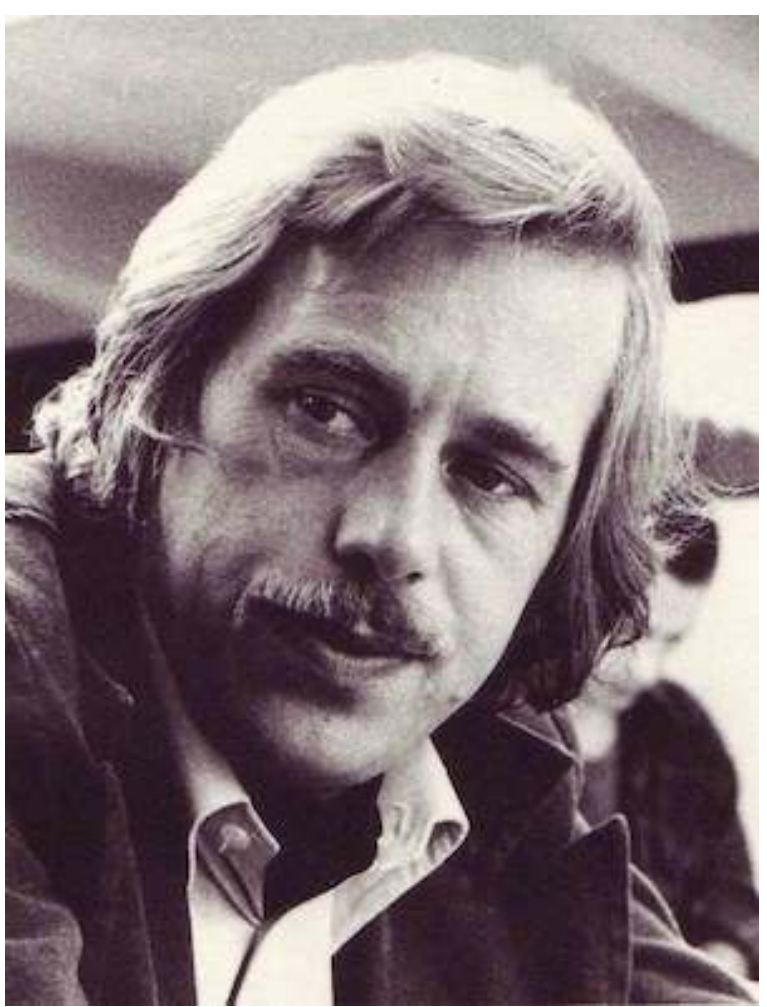

Source: https://www.prague.eu/fr/objet/lieux/2121/bibliotheque-vaclav-havel-knihovna-vaclava-havla 
totalitarian ideology has discovered its Truth, which becomes the only truth, easy to control. Against this stands eclecticism. For Teverson, "Eclecticism implicit in any uncensored grouping of stories, along with the expansiveness and ambiguity of any one narrative, undermine the lust for closure and finitude," and these are, in Haroun and the Sea of Stories, a "threat to Khattam-Shud's power" (Teverson 2001: 450), whose name means 'finished,' 'done-for,' 'the end':

The world is for Controlling [...] Your world, my world, all worlds [...] They are all there to be Ruled. And inside every single story, inside every Stream in the Ocean, there lies a world, a storyworld, that I cannot Rule at all. And that is the reason why [I hate stories so much]. (H 161)

In a totalitarian regime, uniqueness and specificity of imagination have no place. Bureaucratic structure and order together with empty rituals replace the natural disorder of life, and thus life itself and its stories are negated and, indeed, annihilated (Havel 1987).

Khattam-Shud, also appropriately called Cultmaster, and the destructive activities related to his poisonous anti-stories and to the story-source to be shut up by the Plug, are typically accompanied by routine machine-like and clerical work (H 152-6), the life of the Chupwallas and their Shadows being one of pretension: "They put on opposite acts, so nobody knows what they really feel" (H 135). The war between Gup and Chup "was a war between Love (of the Ocean, or the Princess) and Death (which was what Cultmaster Khattam-Shud had in mind for the Ocean, and for the Princess, too)" (H 125). is necessary to move a world - the world of one's own "I " - which Haroun eventually does while moving the Kahani moon. The ice and shadow of Chup disappear under the Sun's warm rays. As the totalitarian rule is abolished, both parts of the moon are (re-)united, a possible allusion to the (re-)unification of Germany in 1989 (as well as to other events, as noted by Teverson [2013: 76]). The kidnapped Princess restored to her family may symbolize the return to a harmonious state of affairs, echoed by Haroun's family reunited in the 'real' world. There is a reversal with Khattam-Shud, as his lot now becomes what he intended for Chup and the story: he is now 'finished,' 'done-for', and has reached 'the end.'

Rushdie's flight of fancy and the construction of an imaginary world are quite naturally read, as has been suggested, as his creative response to the stressful situation caused by the fatwa. His imagination, like Tolkien's, is mythopoetic in that he not only borrows from existing myths but also invents postcolonial myths, such as the myth of free speech in the person of the Shah of Blah.

Mr. Sengupta's initial question, “What's the use of stories that aren't even true?” (H 20), a question with which Haroun has been obsessed during his whole journey, can be precisely found answered by the words of Kakar and Goldman mentioned earlier. While using myth as an "organizer of [Haroun's] experience" (Doniger 1975: 11-2) Rushdie skillfully plays with his child protagonist's "individual psychology as projected onto the outside world" (Kakar 1981: 4). In his story, what is going on "inside" happens "outside." In this way, the stories prove "more rather than less real than life" (Kakar 1990: 3). The sadness and totalitarianism disappear from the life of Haroun and his family as well as from the lives of the inhabitants of the city as they laugh and smile and talk... and finally recall the city's name: Kahani. The rain washes away the smoke of 
the sadness factories ( $\mathrm{H} \mathrm{21)}$, and the water that had made the journey "to the other side" possible is again present and the city, flooded with the sea water, welcomes its heroes back.

\section{Truths}

In stories as well as dreams, "truths that the truth cannot tell can become felt and known" as Rushdie points out (Rushdie 2013: 19). The author had always been concerned with the interaction of the conscious mind and the unconscious. Rushdie uses water imagery and especially sea imagery as convenient tools to drive his point home. In psychology, a passage towards the Other is often represented by a dream or a dreamlike passage in which there is a voyage through a body of water, frequently a sea, as in Midnight's Children (1981) or The Satanic Verses (1988). According to Sudhir Kakar, "psychoanalysis is essentially a telling and retelling a story of a particular life" and the "understanding of the person in India, especially the untold tale of his fears and wishes - his fantasies - requires an understanding of the significance of his stories" (Kakar 1990: 2, 4).

Before Rushdie, West Indian author Wilson Harris was known for his magical use of space to represent alternative realities. Ashcroft, Griffiths and Tiffin claim that he "had a profound belief in the possibilities of (individual and communal) psychic regeneration through catastrophe. By the transforming powers of the imagination, what appears to have been irretrievably lost may be recuperated" (Harris 1985: 127 qtd by Ashcroft et al. 1989. 2001: 150). As has been argued, totalitarianism is directed against story. The intention to plug the sea source of stories is an attempt to destroy the imagination as such, together with the power of transformation represented by the sea. Haroun's chances of getting over the loss of his mother with the help of the healing powers awakened in his unconscious would thus be forever compromised and his psychic regeneration made impossible.

In his magical story, enclosed within the fairy tale frame of a mundane beginning and realistic ending, intended to prepare his son and other children "to better master life" (Bettelheim 2010: 68), Rushdie makes the protagonist Haroun experience what is perhaps the child's most acute trauma, i.e. the loss of his mother. Gonzalez aptly points to the relation between fairy tales and psyche, mentioning "the process of maturation encoded within fairy tales, alluded to by Bettelheim, making of the tale an encounter with the psyche" (Gonzalez 2005: 61). This is true for Haroun's home city too: the trip to the Kahani sea world, the Other, makes it possible for its identity, which represents the complete identity of the Self, to be revealed and defined as Kahani, story. This unites the two components of the Self, the conscious and the unconscious. Rushdie's selfreferential story points to the capacity of imagination which, by retrieving to the conscious part of the mind the elements hidden before in the unconscious, helps the child protagonist grapple with the hitherto hidden reality. To paraphrase Rushdie, his protagonists are swallowers of not just one world (Rushdie 1981: 382), but of worlds as different and varied as all the elements of individual lives, realities, truths and creative geniuses. "Our dreams are the real truths - our fancies, the knowledge of our hearts" (L 157). Our dream-world, which can be accessed by symbolically passing through water, and especially sea water, is our home-world. 


\section{BIBLIOGRAPHY}

Ashcroft, Bill, Gareth Griffiths and Helen Tiffin. The Empire Writes Back: Theory and Practice in Postcolonial Literatures. 1989. London and New York: Routledge, 2001.

Ashcroft, Bill, Gareth Griffiths and Helen Tiffin. Post-Colonial Studies: the Key Concepts. 2000. London and New York: Routledge, 2007.

Bettelheim, Bruno. The Uses of Enchantment: the Meaning and Importance of Fairy Tales. New York: Vintage Books, [1975] 2010.

Doniger, Wendy. Hindu Myths. London: Penguin, 1975.

Durix, Jean-Pierre. “'The Gardener of Stories': Salman Rushdie's Haroun and the Sea of Stories.” In M.D. Fletcher, ed. Reading Rushdie: Perspectives on the Fiction of Salman Rushdie. Amsterdam-Atlanta: Rodopi, 1994. 343-351.

Fanon, Frantz. "On National Culture.” In Patrick Williams and Laura Chrisman. Colonial Discourse and Post-Colonial Theory: A Reader. London: Longman, 1994. 36-52.

Goldman, Robert. "The Serpent and the Rope on Stage: Popular, Literary, and Philosophical Representations of Reality in Traditional India.” Journal of Indian Philosophy 14.4 (1986): 349-369. https://www.jstor.org/stable/23445491

Gonzalez, Madelena. "Haroun and the Sea of Stories: 'The Uses of Enchantment."' In Gonzalez, Madelena. Fiction after the Fatwa: Salman Rushdie and the Charm of Catastrophe. Amsterdam-New York: Rodopi, 2005. 53-72.

Havel, Václav. "Př́běh a totalita." Revolver Revue. 1987. http://www.vaclavhavel.cz/ showtrans.php?cat=clanky\&val=77_clanky.html\&typ=HTML

Trans. Paul Wilson, "Stories and Totalitarianism."

Harris, Wilson. “Adversarial contexts and creativity.” New Left Review 1/154 (NovemberDecember), 1985: 124-8. https://newleftreview.org/issues/I154/articles/wilson-harrisadversarial-contexts-and-creativity

Innes, C. L. The Cambridge Introduction to Postcolonial Literatures in English. Cambridge: Cambridge UP, 2007.

Kakar, Sudhir. Indian Identity. New Delhi: Penguin India, 2007.

Kakar, Sudhir. Intimate Relations: Exploring Indian Sexuality. New Delhi: Penguin Books, [1989] 1990.

Kakar, Sudhir. The Inner World. Oxford: Oxford UP, 1981.

Kakar, Sudhir and Katharina Kakar. The Indians: Portrait of a People. Delhi: Viking Penguin, 1997.

Patel, Vibhuti. “Salman Rushdie and His Mythic Legacy”. Wall Street Journal. November 27, 2010. http://online.wsj.com/article/SB10001424052748704638304575636763279031150.html

Rollason, Christopher. “An Unsurprising World of Magic? - Review of Salman Rushdie, Luka and the Fire of Life.” 2011. http://yatrarollason.info/files/RushdieLuka.pdf

Roy, Arundhati. The God of Small Things. London: Flamingo, 1997.

Rushdie, Salman. Midnight's Children. London: Picador, [1981] 1982.

Rushdie, Salman. The Satanic Verses. New York: Viking, 1988. 
Rushdie, Salman. Haroun and the Sea of Stories. London: Granta Books, 1991. Referred to as H.

Rushdie, Salman. Luka and the Fire of Life. London: Vintage, [2010] 2011. Referred to as L.

Rushdie, Salman. Joseph Anton. New York: Random House, [2012] 2013.

Teverson, Andrew S. "Fairy Tale Politics: Free Speech and Multiculturalism in Haroun and the Sea

of Stories." Twentieth-Century Literature 47.4 (Winter 2001): 444-466. DOI: 10.2307/3175990

Teverson, Andrew S. “Salman Rushdie's Post-Nationalist Fairy Tales: Haroun and the Sea of Stories and Luka and the Fire of Life. In Robert Eaglestone and Martin McQuillan, eds. Salman Rushdie.

London: Bloomsbury, 2013. 72-85.

Zimmer, Heinrich. Myths and Symbols in Indian Art and Civilization. Princeton: Princeton UP, 1992.

\section{ABSTRACTS}

As in works by other Indian writers, water as a symbol plays a crucial role in several novels by Salman Rushdie, the imagery being rooted in the Hindu worldview. Protagonists who find themselves immersed in bodies of water, be it in Midnight's Children (1981) or The Satanic Verses (1988), are not the same people when they come out of them (if they do). This is true also for Rushdie's two works for children, Haroun and the Sea of Stories (1991) and Luka and the Fire of Life (2010). In the former, the author introduces different worlds that are nevertheless interconnected, each with a reality of its own. Haroun, the child protagonist, travels from the world of apparent everyday reality (represented by planet Earth) to a Moon world called Kahani. The journey to, and on, the sea waters that cover a large portion of Kahani depicts an entirely different dimension of reality. Stories and dreams occurring in this land of fiction symbolize the healing power of the imaginary. This article proposes an analysis of this literary material using the Hindu worldview as a point of departure and elaborating on the different aspects of Rushdie's representation of the sea.

Comme pour d'autres auteurs indiens, l'eau comme symbole joue un rôle crucial dans plusieurs romans de Salman Rushdie, l'imagerie aquatique étant enracinée dans une vision du monde hindoue. Les protagonistes immergés dans des masses d'eau, que ce soit dans les Enfants de Minuit (1981) ou Les Versets sataniques (1988), ne sont pas les mêmes lorsqu'ils en ressortent (s'ils y parviennent). Cela est vrai aussi pour les deux livres pour enfants de Rushdie, Haroun et la Mer des histoires (1991) et Luka et le feu de la vie (2010). Dans le premier, l'auteur présente des mondes différents et néanmoins liés, chacun avec une réalité propre. Haroun, l'enfant protagoniste, se déplace du monde de la réalité quotidienne apparente (représentée par la planète Terre) pour aller vers un monde lunaire appelé Kahani. Le voyage aux sources et à travers les eaux de la mer qui couvrent la majeure partie de Kahani représente une dimension entièrement différente de la réalité. Les histoires et les rêves qui ont lieu sur cette terre de fiction symbolisent le pouvoir guérisseur de l'imaginaire. Cet article propose d'analyser ce matériel littéraire, utilisant la vision du monde hindoue comme point de départ pour étudier les différents aspects de la représentation de la mer chez Rushdie. 


\section{INDEX}

Keywords: sea, story, storytelling, I/self, Hindu cosmology, totalitarianism, Rushdie Salman, India, water, literature, children's literature

Mots-clés: mer, histoire, narration, Je/soi, cosmologie hindoue, totalitarisme, Rushdie Salman, eau, Inde, littérature, littérature pour enfants

\section{AUTHOR}

\section{LUDMILA VOLNÁ}

Ludmila Volná is Lecturer in English at Charles University, Prague, and associate member of ERIAC, Université de Rouen Normandie, and IMAGER, Université Paris-Est Marne-la-Vallée. She teaches M.A. courses on Indian writing in English and her research includes Indian and Czech literatures and cultures. She has several co-edited volumes to her credit, e.g. Children of Midnight: Contemporary Indian Novel in English (Pencraft International, 2012) and Education et Sécularisme: Perspectives africaines et asiatiques (L'Harmattan Paris, 2013), as well as a number of papers published in anthologies and peer-reviewed journals and presented as invited lectures and conference papers in Europe, Africa, North America and Asia. A member of several academic associations including SARI, of which she is currently a Vice-President, and the non-India membership representative at IACLALS (Delhi), Ludmila Volná is also active on editorial and advisory boards of several academic journals. Contact: ludmila.volna[at]free.fr 